\title{
Information ethics: why and how we teach the subject (Turkey)
}

\author{
Ayşe Yüksel Durukan \\ yuksel.ayse@gmail.com
}

School librarians have always strived to teach information ethics to students. The importance of conveying the concept of information ethics to students has become critical within the overwhelming effect of data and information flow. In an age of massive information flow we need to address the issues related to that subject: ethics vs. wrongdoing, propoganda vs. accuracy, bias vs. neutrality, prejudice vs. objectivity, self opinionatedness vs. flexibility, fiction vs. documentary, fact vs. opinion.

Turkish communities largely depend on oral culture. The codes of a written culture maybe unknown to some part of the population. In Turkey generally school librarians are not expected to teach. Most schools may not even have a certified librarian. Those who happen to work at schools are not expected to have a teaching certificate. Teachers at schools who speciliaze on subjects may teach about ethics, in case the issue is in question. Primary years programme has scheduled the subject Thinking in education which involves a chapter on citizenship and democracy education; the subject is offered as a elective. High school grades 10 and 11 will study philosphy but Being, Ethics, Art and Religion topics are undervalued. We as school librarians can fill in the gaps. We need to be role models in teaching media literacy, academic honesty and integrity, and above all the culture of information. Collaboration with teachers is a necessity, teaching information ethics related to the student lives, with direct examples drawn from their life-experiences are very important. If we teach the subject in a dull way, with irrelevant examples it makes no sense to them and they can easily disconnect. We need to adddress the issue of using text online, voice call, images and videos, the differences and similarities. We need to be information curators for our communities.

Keywords: information ethics, school libraries, LIS and Turkey

\section{Introduction}

$\mathrm{S}$ chool librarians have always strived to teach information ethics to students. As information managers at schools they have dealt with the classification, organization, flow, use, sharing, creation, and dissemination of information. The importance of conveying the concept of information ethics to students has become critical within the overwhelming effect of data and 
information and disinformation flow. The attractiveness of social media and the colorful digital world of gadgets for young adults have even made it more significant; because whatever data or information, whether reliable or not, that reaches them may be taken seriously, and can cause undesirable situations.

\section{Ethics story}

As human beings we all grow up learning to behave with moral principles through sayings and stories. As children we are told to tell the truth by our parents or by elderly members of our families. As students we learn to behave ethically within the school community and society. All religions preach and praise truth. Every profession has its code of ethics on seeking truth, moral behavior and respecting diverse cultures. These are the principles of conduct that teach and remind us on how to behave, what is acceptable and what is not.

In an age of massive information flow we need to address the issues related to that subject: ethics vs. wrongdoing, propaganda vs. accuracy, bias vs. neutrality, prejudice vs. objectivity, self opinionatedness vs. flexibility, fiction vs. documentary, fact vs. opinion.

UNESCO addresses the universal truth, "Ethical principles for knowledge societies derive from the Universal Declaration of Human Rights and include the right to freedom of expression, universal access to information, particularly that which is in the public domain, the right to education, the right to privacy and the right to participate in cultural life" (UNESCO, 2017).

IFLA touches on the librarians' fundamental role "To enhance access for all, librarians and other information workers support people in their information searching, assist them to develop their reading skills and information literacy, and encourage them in the ethical use of information (with particular attention to the welfare of young people)" (IFLA, 2016).

ALA code of Ethics goes, "Ethical dilemmas occur when values are in conflict. The American Library Association Code of Ethics states the values to which we are committed, and embodies the ethical responsibilities of the profession in this changing information environment" (ALA, 2008). We are indeed in a world of different points of view, therefore resolving ethical dilemmas may not be simple. 
All of these points raise the issue of consciousness on ethics and ethical behavior. Moreover the shift toward digital communication in all realms demands different skills and tools to be able to cope with.

Around the world diverse or heterogeneous cultures may differ about ethical values; I strongly believe universal ethics should adhere to the same standards. To understand different cultures we need to look into the past, history of how the mindset of those cultures has evolved.

In general terms, without regard to exceptions, before Gutenberg, information circulated orally, only a few had the privilege of accessing books. The distribution of information on clay, papyrus, wax, and parchment was problematic; and after the handwritten- book- period was over, the printing press allowed access to crowds, Gutenberg's technology expanded the increase in the availability of books. Information was no longer a privilege that was in the hands of the few. That was the fifteenth century and especially for Europe.

\section{Turkey}

For Turkey the establishment of the printing press took place in 1729 by a Hungarian convert, İbrahim Müterferrika. Not too many books were published at first: from 1729 to 1928 only 30,000 books were published due to political and religious reasons (Doğan, 2009). The translation of works from western literature also helped the enlightenment and sharing new information. The very first newspaper by the state started in 1831 (Takvim-i Vekayi) and the first private one (Ceride-i Havadis) in 1840 which helped the information flux. The telegraph was introduced in 1847 and the telephone in 1908 and the radio in 1927. The masses had to wait for the announcement of the Republic (1923) for equal and more access to information.

Even today Turkish communities largely depend on oral culture. The codes of a written culture maybe not be familiar to them. The codes of the oral language are communicating through talking, applying the common sense mindset, depending on particular concrete events, allowing 
for contradictions and subjectivity whereas written language communicates through text, representing scientific and philosophical knowledge, abstracting, allowing for generalizations and objectivity. In Turkey, TV was introduced in 1968 and there was only one channel broadcast for the next 22 years. TV did not improve the written language codes but increased the oral language enthusiasm. People enjoyed listening to the screen stories at home. The Internet expanded in 1990 and the smart phone multiplied in 2010. Talking on the phone and sending messages in different formats, text, whether correct or incorrect, images, related or not, relevant or irrelevant or disinformation flow affects all groups.

The illiteracy rate over six years of age in Turkey is $5.4 \%$ : women constitute \% 5, 4 and men \%1, 8. (Turkish Statistical Institute, 2017).

Also a survey run by Kadir Has University called 'Research on Social and Political Trends 2018,' questioned people above ages 18 , and as a result $52,8 \%$ of the respondents did not read at all, only $5,9 \%$ was interested in reading books every day. However, $44,8 \%$ watched TV between 1 3 hours; 31, 5\% 3-5hours; $10 \%$ spend more than 5 hours a day. With social media and gaming people pass 44, 7\% 1-3 hours a day, 17, 3\% 3-5 hours a day (Kadir Has University Center for Turkish Studies, 2018). More than half of grownups do not read at all whereas watching TV and preferring social media and gaming are more popular activities.

\section{School Libraries}

As of 2017 there are 1137 public libraries in the country. Of these 127 are closed, not functioning. The city that takes the lead is Diyarbakır with 7 public libraries, and Kastamonu and Nevşehir with 6 shut down libraries. Turkey’s population is 78 million (Turkish Statistical Institute, 2017).

There are 62,250 K-12 schools in Turkey as reported for the 2016-2017 educational year. The number of students attending schools is 17,319,433; the number of teachers is 1,500,380. 109,000 teachers need to be appointed; Turkey desperately needs teachers and school librarians. The number of school libraries is 27,283 and the number of Z-Libraries - Enriched libraries is 1260 (Turkish Ministry of Education, 2017). 
Enriched libraries is a project that started at the end of the year 2014; it is an attempt to rejuvenate and support school libraries. Unfortunately, not all schools have libraries and all schools do not have certified school librarians.

In Turkey generally school librarians are not expected to teach. Most schools may not even have a certified librarian. All university information studies teach the same subjects and a student who studies librarianship graduates without differentiation as academic, special, archivist, public or school librarian. Those who happen to work at schools learn the subtleties of the profession while working. Some private schools and those schools who pursue accreditation from IB organizations demand such specifications. A professionally trained school librarian with a teaching certificate will make every school benefit in many aspects.

2017 Annual report of the Ministry of Education indicates that the number of books targeted for primary school students states that students should read 25 books a in an educational year, but the result came out as 20.84. While the target was 9 in secondary schools, at the end of the educational year the number was 8.10. As for high schools the target was 5, the number stayed 4.72 through the year. Library and reading statistics are not satisfactory. The appointed objectives were not exactly fulfilled (T.C. Milli Eğitim Bakanlığı, 2018). The school librarians can play a crucial role here. Promotion of reading programs by school librarians will enhance the reading culture in the country.

The book publishing market does not look so disappointing: in 2017 60,335 titles were published in Turkey and that ranks the country as 11th among the world market (Turkish Publishers Association, 2017).

\section{Curriculum on ethics}

Teachers at schools who specialize on subjects may teach about ethics, in case the issue is in question. Primary year planners have scheduled the subject "Thinking in education" which involves a chapter on citizenship and democracy education as an elective. High school grades 10 
and 11 will study philosophy, 2 hours a week, but Being, Ethics, Philosophy of Art and Philosophy of Religion chapters are abridged. These subjects are seen as subsidiary areas. The school librarians can fill in the gaps. In light of these features school librarians can find ways to enlighten students on media literacy and information literacy. The difference between fact and opinion should be clear to the students from early stages. As John Dewey said "We can have facts without thinking, but we cannot have thinking without facts."

The word of the year in 2016 was "post-truth" by Oxford dictionaries; in 2017 the word was "youth quake", "feminism" was chosen by Merriam Webster and "fake news by Collins dictionaries. These issues are warnings for school librarians. They have to be alert in guiding the students to becoming responsible citizens of the world, especially when they are dealing and spending time on social media. All is related to the field of the profession. The European Commission published a multi-dimensional report on fake news and online disinformation developing tools for empowering users to tackle disinformation: "For media and information to be effective, it must be implemented on a massive scale in school curricula and in teacher training curricula, with clear methods of evaluation and cross-country comparison and with reflection in educational rankings gauges" (European Commission, 2018).

\section{What School Librarians Can Do?}

School librarians must be able to teach the ecosystem of information on all platforms. They need to educate students on how to formulate questions, how to evolve into successful researchers, how to become problem solvers and evaluators, creators of new knowledge and above all embracing the culture of information. They need to be role models in teaching media literacy, academic honesty and integrity, digital citizenship, how to understand what disinformation is and the consequences. We need more libraries and functioning libraries. School Librarians should be entitled to receive pedagogical training. They should provide instruction on how to use databases, apps, searching the Internet, library resources. Collaboration with teachers is a necessity, teaching information ethics related to the student lives, with direct examples drawn from their life experiences is very important. If they teach the subject in an ordinary way, with irrelevant examples it makes no sense to the students and they can easily disconnect. All the topics should be customized and correlated to the lessons in order to render meaning for the students. They need 
to address the issue of using text online, voice call, images and videos, the differences and similarities. They all must be information curators.

International Association of School Librarianship https://www.iasl-online.org/ 


\section{References}

ALA. (2008, January 22). Professional Ethics. Retrieved from http://www.ala.org/tools/ethics

Doğan, A. N. (2009, August 7). Türkiye'de yayıncılık - Osmanlı Devleti'nde kitap yayıncılığı/Kültür - Sanat/milliyet blog. Retrieved from http://blog.milliyet.com.tr/turkiye-de-yayincilik---osmanli-devleti-nde-kitapyayinciligi/Blog/?BlogNo=195709

European Commission. (2018, March 12). Final report of the High Level Expert Group on Fake News and Online Disinformation. Retrieved from https://ec.europa.eu/digital-singlemarket/en/news/final-report-high-level-expert-group-fake-news-and-onlinedisinformation

IFLA. (2016, December 27). IFLA -- IFLA Code of Ethics for Librarians and other Information Workers (short version). Retrieved from https://www.ifla.org/publications/ifla-code-ofethics-for-librarians-and-other-information-workers--short-version-

Kadir Has University Center for Turkish Studies. (2018, January 31). Research on Social and Political Trends in Turkey. Retrieved from http://www.khas.edu.tr/news/1777

T.C. Milli Eğitim Bakanlığı. (2018). MEB Faaliyet Raporu. Retrieved from http://sgb.meb.gov.tr/meb_iys_dosyalar/2018_02/28093718_Faaliyet_Raporu_yayYn_28 022018_1707.pdf

Turkish Ministry of Education. (2017). Milli Eğitim Bakanlığı Z-Kütüphane Haritası. Retrieved from http://z-kutuphane.meb.gov.tr:8076/zharita.html

Turkish Publishers Association. (2017). 2017 Türkiye Kitap Pazarı Raporu - Türkiye Yayıncılar Birliği. Retrieved from http://turkyaybir.org.tr/2017-turkiye-kitap-pazariraporu/\#.WtXn2IhubIV

Turkish Statistical Institute (TurkStat). (2017, August 2). Turkish Statistical Institute Library Statistics 2016. Retrieved from http://www.turkstat.gov.tr/PreHaberBultenleri.do?id=24675

Turkish Statistical Institute (TurkStat). (2017, March 7). Turkish Statistical Institute Women in Statistics 2016. Retrieved from http://www.turkstat.gov.tr/PreHaberBultenleri.do?id=24643

UNESCO. (2017). Information Ethics | United Nations Educational, Scientific and Cultural Organization. Retrieved from http://www.unesco.org/new/en/communication-andinformation/intergovernmental-programmes/information-for-all-programmeifap/priorities/information-ethics/ 


\section{Biographical Note}

Ayse Yuksel-Durukan received her BA from Robert College and MLIS from Dominican University, Illinois, USA. She studied fine arts at Mimar Sinan University (MA), Istanbul, Turkey. She has been working with school librarians since 2000, she initiated and arranged the 1st National School Librarians' Conference in 2003 at Robert College. She worked at Robert College Library Media Center untill 2013 and has been lecturing about libraries and educational events. She is a member of Turkish Librarians Assoc.,IBBY, IASL, ALA, AASL, and has a Beta Phi Mu award. She acted as director of the Middle East \& North Africa of IASL 2012-2018. She is involved with the Enriched Libraries project of the Turkish Ministry of Education. She is also acting as a coordinator of the school library of Terakki Schools. 